findings contrast strikingly with those reported by others. ${ }^{2}$ Despite this heterogeneity of response, all the women conceived during treatment with luteinising hormone releasing hormone, so the absence of a normal or even of a detectable response in a standard intravenous luteinising hormone releasing hormone test did not exclude a satisfactory response to treatment (table)-nor did the presence of a normal response exclude a failure (unpublished observations).

Classifying these patients according to their response in the luteinising hormone releasing hormone diagnostic test ${ }^{3}$ was of no value whatever in predicting the response to treatment with luteinising hormone releasing hormone. Three pregnancies occurred with subcutaneous treatment in patients in group 1; and one patient in group 4, who needed intravenous treatment to induce ovulation, had had an exaggerated response in the diagnostic test. The one patient who over-responded to treatment was from group 2, and neither the luteinising hormone nor follicle stimulating hormone concentrations obtained in the diagnostic tests predicted any feature of this outcome of treatment.

We conclude that the standard intravenous $100 \mu \mathrm{g}$ luteinising hormone releasing hormone diagnostic test offered no help in the clinical classification of our patients with amenorrhoea, failed to assess the therapeutic potential of treatment with luteinising hormone releasing hormone, and failed to distinguish between those patients needing intravenous and those needing subcutaneous treatment. We therefore consider it useless as a clinical test.

1 Mortimer $\mathrm{CH}$, Besser GM, McNeilly AS, et al. Luteinising hormone and follicle stimulating hormone-releasing hormone test in patients with hypothalamic-pituitary-gonadal dysfunction. BrMed f 1973;iv:73-7.

2 Aono T, Minagawa J, Kinugasa T, Miyake A, Kurachi K. The diagnostic significance of LHreleasing hormone test in patients with amenorrhea. Am f Obstet Gynecol 1973;119:740-8.

3 Leyendecker $G$, Wildt $L$. Treatment of infertility with pulsatile administration of gonadotropinreleasing hormone in hypothalamic amenorrhea. In: Leyendecker G, Stock H, Wildt LH, eds. Brain and pituitary peptides II. Ferring symposium, Kiel, 1982. Basle: Karger, 1983:89-112.

4 Adulwahid NA, Adams J, Van Der Spuy ZM, Jacobs HS. Gonadotrophin control of follicular development. Clin Endocrinol (Oxf) (in press).

(Accepted 30 August 1985)

Cobbold Laboratories and Department of Ultrasonography, The Middlesex Hospital, London W1

N A ADULWAHID, MB, CHB, research fellow

N A ARMAR, MRCOG, research fellow

D V MORRIS, MRCP, senior registrar

J ADAMS, DCU, senior ultrasonographer

H S JACOBS, MD, FRCP, professor of reproductive endocrinology

Correspondence to: Professor H S Jacobs, Cobbold Laboratories.

\section{Treatment of salicylate poisoning with repeated oral charcoal}

Activated charcoal is a powerful non-specific absorbent that has long been used in attempts to limit gastrointestinal absorption after drug overdose. To be effective in this way it must be given in adequate dosage within an hour after ingestion of the poison, and this limits its usefulness. Recently, repeated administration of oral charcoal has been shown to enhance elimination of therapeutic doses of drugs such as anticonvulsants, dapsone, and theophylline, ${ }^{12}$ and in our experience it is highly effective in the treatment of overdosage with phenobarbitone. Repeated oral administration of activated charcoal also rapidly reduces plasma salicylate concentrations after overdosage of aspirin.

\section{Case reports}

Four men and one woman aged $19-59$ had maximum plasma salicylate concentrations of $425-655 \mathrm{mg} / \mathrm{l}$ two to eight hours after taking aspirin in overdose. All the men had taken alcohol; in addition, one patient (case 1) had taken a benzodiazepine and another (case 2) paracetamol (not requiring specific treatment). Gastric lavage was performed in all patients on admission. Two patients (cases 3 and 4) had maximum plasma salicylate concentrations of 640 and $655 \mathrm{mg} / \mathrm{l}$ respectively and were initially treated by forced alkaline diuresis. They were given charcoal 12 and 15 hours after diuresis was completed because of an unsatisfactory response. In four patients (cases 1-4) activated charcoal (Medicoal) was given orally suspended in $200 \mathrm{ml}$ water in an initial dose of $75 \mathrm{~g}$ followed by $50 \mathrm{~g}$ every four hours until symptoms were relieved. The fifth patient (case 5) received $50 \mathrm{~g}$ charcoal at $\mathrm{two}$, six, and 10 hours after the initial $75 \mathrm{~g}$ dose. Cathartics were not given.

Plasma salicylate concentrations after administration of charcoal were compared with those in six control patients with mild aspirin poisoning treated by oral fluids alone. In every case plasma salicylate concentrations fell dramatically after the administration of charcoal (figure). The mean maximum rate of removal

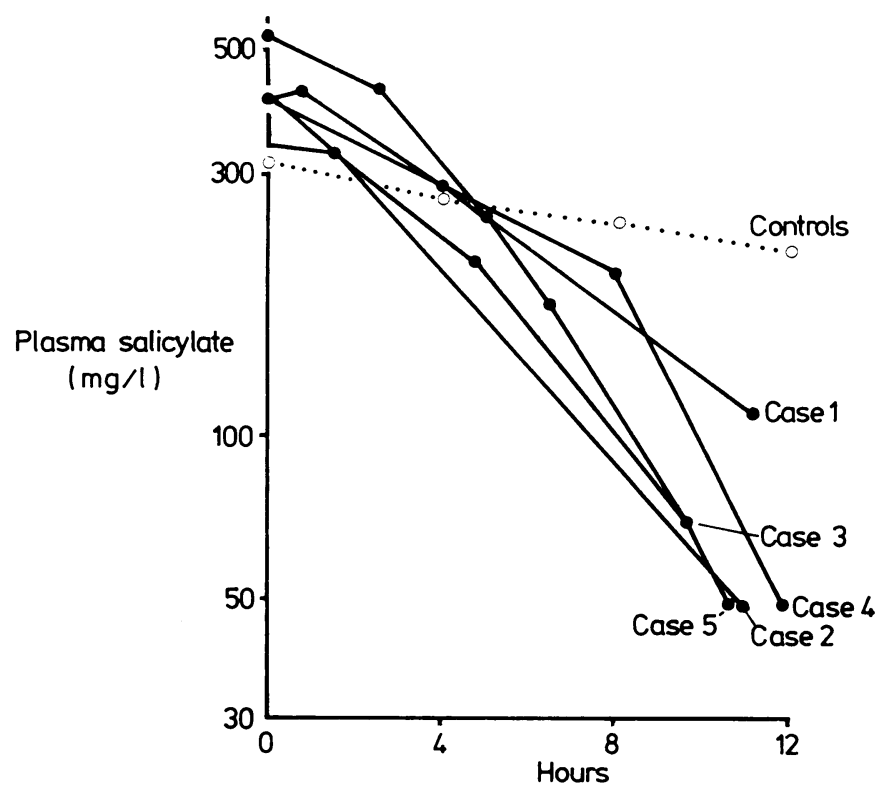

Plasma salicylate concentrations in five patients after overdosage of aspirin receiving repeated oral charcoal from time 0 . Also shown are mean salicylate concentrations over a comparable period in six control patients given only oral fluids. Lowest plasma salicylate concentrations in cases 2 and 4 were below 50 $\mathrm{mg} / \mathrm{l}$.

corresponded to a half life of less than $3 \cdot 2$ hours and in one patient (case 2 ) was less than two hours. In contrast, the plasma half life in the control group was 27 hours.

\section{Comment}

Repeated oral administration of activated charcoal can appreciably enhance the elimination of phenobarbitone and dapsone after overdosage, ${ }^{13}$ but its use in salicylate poisoning has not been reported previously. The elimination of salicylate is concentration dependent, and after overdosage the plasma half life is about 30 hours without treatment. ${ }^{4}$ In all our patients charcoal produced a rapid fall in the plasma salicylate concentration, and it appeared to be more effective than forced alkaline diuresis. ${ }^{4}$ It cannot be assumed, however, that repeated treatment with oral charcoal will be as successful in patients with more severe intoxication, which might be complicated by vomiting or reduced gastrointestinal motility. The type of charcoal used and the dose regimen may be important, and cathartics should obviously be avoided. Repeated administration of oral charcoal probably acts by irreversibly binding drug that diffuses from the circulation into the gut lumen. Such "gastrointestinal dialysis"s does not depend on enterohepatic circulation and would probably be most effective with acidic drugs which have a small volume of distribution. Repeated oral administration of activated charcoal is safe and relatively cheap. Further studies are required in severe poisoning with aspirin and other drugs.

1 Neuvonen PJ. Clinical pharmacokinetics of oral activated charcoal in acute intoxications. Clin Pharmacokinet 1982;7:465-89.

Perlinger WG Spector R, Goldberg MJ, Johnson GF, Quee CK, Berg MJ. Enhancenent Berlinger WG, Spector R, Goldberg MJ, Johnson GF, Quee CK, Berg MJ. Enhancen
theophylline clearance by oral activated charcoal. Clin Pharmacol Ther 1983;33:351-4.

3 Pond SM, Olson KR, Osterloh JD, Tong TG. Randomized study of the treatment of phenobarbital overdose with repeated doses of activated charcoal. FAMA 1984;251:3104-8.

4 Prescott LF, Balali-Mood M, Critchley JAJH, Johnstone AF, Proudfoot AT. Diuresis or urinary alkalinisation for salicylate poisoning? Br Med $\mathcal{F}$ 1982;285:1383-6.

5 Levy G. Gastrointestinal clearance of drugs with activated charcoal. N Engl I Med 1982;307:676-8.

(Accepted 1 August 1985

Regional Poisoning Treatment Centre and University Department of Clinica Pharmacology, Royal Infirmary, Edinburgh EH3 9YW

R J HILLMAN, BSC, MB, senior house officer in medicine

L F PRESCOTT, MD, FRCPED, professor of clinical pharmacology

Correspondence to: Professor Prescott.

\section{Correction}

Exchange transfusion and quinine concentrations in falciparum malaria

An error occurred in this article by Dr Anthony Hall and others (26 October, p 1169). In the text (at the end of the third paragraph and in the fourth paragraph) and in the table plasma quinine concentrations were given in $\mathrm{mmol} / \mathrm{l}$; these should have been $\mu \mathrm{mol} / 1$ 